\title{
The Validity Of Marriages Agreement Made After Ongoing Based Marriage Law In Indonesia
}

\author{
Intan Fajriyanti ${ }^{1}$, Joko Hermawan Sulistyo ${ }^{2}$ and Munsyarif Abdul Chalim ${ }^{3}$ \\ Abstract. Mating agreement has been stipulated in Article 29 of Act No. 1 Of 1974. \\ Married to the present agreement remains in the society. The problems examined in \\ this study is: what are the factors occurrence marriage agreement, how the validity of \\ the agreement to marry, and the legal consequences mating agreement executed after \\ the course of the marriage. The method used is a normative legal research. The result \\ of the first conclusion that the arrangement agreement are married in Indonesia in the \\ Act include the Civil Code, the Marriage Act No. 1 of 1974, KHI and the Constitutional \\ Court Decision No. 69 / PUU-XIII / 2016, and at the conclusion of research results \\ mating agreement made after the course of a legal marriage do not violate the \\ boundaries of the law, religion, and morality. \\ Keywords: Agreement; Mating Agreement; Marriage Law.
}

\section{Introduction}

Mating agreement is an agreement made by two people (prospective husband and wife) before the holding of their marriage, to manage the consequences of the marriage that involves wealth. ${ }^{4}$

Marriage is the intimate union and equal partnership of a man and a woman. It comes to us from the hand of God, who created male and female in his image, so that they might become one body and might be fertile and multiply (See Genesis chapters 1 and 2). Though man and woman are equal as God's children, they are created with important differences that allow them to give themselves and to receive the other as a gift.

Marriage is both a natural institution and a sacred union because it is rooted in the divine plan of creation. In addition, the Catholic Church teaches that the valid marriage between two baptized Christians is also a sacrament - a saving reality and a symbol of Christ's love for his church (See Ephesians 5:25-33). In every marriage the spouses make a contract with each other. In a sacramental marriage the couple also enters into a covenant in which their love is sealed and strengthened by God's love.

The free consent of the spouses makes a marriage. From this consent and from the sexual consummation of marriage a special bond arises between husband and wife. This bond is lifelong and exclusive. The marriage bond has been established by God and so it cannot be dissolved.

The mutual love of a married couple should always be open to new life. This openness is expressed powerfully in the sexual union of husband and wife. The power to create a child with God is at the heart of what spouses share with each other in sexual intercourse. Mutual love includes the mutual gift of fertility. Couples who are not able to conceive or who are beyond their child-bearing years can still express openness to life. They can share

\footnotetext{
${ }^{1}$ Students of Master of Notary Law Faculty of Law Universitas Islam Sultan Agung Semarang email: intanfajriyanti03@gmail.com

2 Students of Master of Law, Faculty of Law, Universitas Islam Sultan Agung email hermawan9390@gmail.com

${ }^{3}$ Lecturer in Faculty of Law Universitas Islam Sultan Agung Semarang

${ }^{4}$ R. Soetojo Prawirohamidjojo 2000 Hukum Orang Dan Keluarga (Personen En FamilieRect) Airlangga University Press Surabaya p.73.
} 
their generative love with grandchildren, other children and families, and the wider community.

Mating agreement provides protection for a husband and wife will be bound in a marriage. Mating agreement made to resolve negative votes for couples wishing to enter into marriage when one party comes from a humble family, while the other party comes from a family in business.

Unlike other countries, Indonesian law has no provision for non-religious civil marriages. The validity of marriage is governed by the Marriage Law of 1974 which took affect in 2nd January 1974. The mixed-marriage couple needs to pay attention to the legal issues surrounding their union. If something unforeseen happens down the line, lack of legal requirements in your marriage will put you into an unfavorable condition. If the law doesn't recognize your marriage, you are considered to be not marriage at all. This lack of a legal status will affect your divorce, division of marital properties, alimony, and child custody.

Indonesia's 1974 Marriage Law stipulates that marriage can be legally recognized if it is performed according to the religion of the two parties. In Indonesia religion is the main issue in marriage. Marriages between different religions is not allowed in Indonesia. Both spouses must have the same religion in order to get marry legally ${ }^{5}$.

Once you have made the decision to marry in Indonesia, you must choose the type of religious ceremony that you intend to have. For Non-Moslems, you must hold a church (or temple) ceremony first, and then record the marriage with the Civil Registry Office. The couple will experience two types of ceremonies. The religious ceremony will be performed first, followed by a civil ceremony. The Civil Registry will in turn issue a Marriage Certificate, which is evidence that you are legally married. A Non-Moslem wedding which is not recorded with the Civil Registry is not considered legal. There will be two certificates presented at the end of ceremony, one from the church/temple, and one from the Civil Registry Office ${ }^{6}$.

If you have decided the marry in a Moslem ceremony, you must register your marriage at the local Office of Religious Affairs (Kantor Urusan Agama/KUA). Persons wedded in a Moslem ceremony are issued a Marriage Book and need not record their marriage with Civil Registry Office.

Considering that Indonesian law has no provision for non-religious civil marriages, the couple who wishes to perform a civil wedding should provide the religious marriage certificate first (i.e. Certificate of Marriage Solemnization), which means that they have completed the religious marriage in their country. Some foreign tourists who get married while on their vacation/honeymoon in Indonesia, choose this route.

Mixed-marriage couples married in Indonesia should pay attention to this issue, especially if they have married in Moslem ceremony. The Moslem Marriage Book is NOT accepted in several countries - for example, Netherlands. The immigration regulations in the Netherlands require a Certificate of Attestation from the Indonesian Civil Registry Office. This is the certificate that show that the marriage has been registered with the Indonesian Civil Registry Office in order to register at the Civil Registry Office in the Netherlands. You need to submit supporting documents such as your passports, visa, marriage books, and photographs (with groom on the right side).

Theoretically, this is may sounds odd. The Office of Religious Affairs and the Civil Registry Office are the Indonesian government institutions that have the authority to record your

\footnotetext{
${ }^{5}$ https://indonesia.embassy.gov.au/jakt/marriageind.html accessed on 02 December 2018

6 Ibid.
} 
marriage. But, in actual practice, you will experience numerous legal difficulties iif you are not fully aware of the legal consequences of your actions.

If you go to the Surabaya Civil Registry Office, they will not issue a Certificate of Attestation based on the Moslem Marriage Book. They don't even want to provide the letter of rejection either. They find Office of Religious Affairs has the same position as them, believing that they are not authorized to issue such certificate ${ }^{7}$.

According to the Regional Autonomy Law of 2004, the regulation for civil registry and population services is the sole responsible of local municipal offices. So, the Surabaya Municipal offices is fully within its authority to consider that the Religious Affairs and Civil Registry take the same legal position ${ }^{8}$.

Another matter that deserves attention is document legalization. Immigration-related documents require certifications or legalizations or authentications in order to be recognized internationally.

The legalization rules are different for each country. Not all information is provided clearly and regulations are not the same in every country. This conflicting information is typical of government bureaucracy all over the world. As we are aware, US rules specify that your certificate(s) should be less than a year old. As for the Netherlands regulations, the certificate(s) should be less than five years old. The process is usually complicated and in many cases a lack of time or expertise can cause delays and valuable time will be lost.

Indonesia is not a part of the Hague Convention, a group of nations joined to create a simplified method of legalizing documents for universal recognition. Therefore, you need an Embassy Legalization for your documents to be valid internationally.

As a non-member of the Hague Convention, Indonesian documents must fulfill certain requirements before the foreign embassy can legalize your documents. Indonesian documents should first pass the procedures at the related government institutions in Indonesia, such as Notary Public certification, Civil Registry, Ministry of Justice, Ministry of Foreign Affairs, and/or Ministry of Religion.

The mixed-couple who has decided to get marry abroad, will not be exempted from the law. The 1974's Marriage Law stipulates that within one year after your return to Indonesia, you must report the marriage to the Civil Registry Office. You will be presented a Surat Tanda Bukti Laporan Perkawinan (STBLP). This certificate is very important and will make your marriage recognized by Indonesian law. Even if you have decided not to stay in Indonesia, this certificate is a must-have document. You never know what will happened in the future and something may cause you to move back to Indonesia. By then, complications will arise in your case due to the long interval of time. You will need to get a court decree in order for your marriage to be recorded at civil registry office. It will ensure additional hassles if you choose to deliver a baby in Indonesia in the future. You cannot get the foreign birth certificate for the baby if you do not possess a STBLP. In addition to the STBLP, it is also a very important document if you would like to own property in Indonesia. The Notary Public will require an Indonesian marriage certificate, whether it's a STBLP or a regular marriage certificate. Your overseas marriage certificate will NOT be accepted because your marriage is not recognized by Indonesian law.

Mating agreement as stipulated in article 29 of Act No. 1 of 1974 on Marriage ${ }^{9}$ and can be about anything, as long as it does not violate the limits of the law, religion and morality.

\footnotetext{
7 Ibid.

$8 \quad$ https://www.voanews.com/a/in-indonesia-interfaith-marriage-is-legal---but-with-manyobstacles-/4373874.html accessed on 02 December 2018

${ }^{9}$ Law No. 1 of 1974 on Marriage
} 
Agreement mating Islamic law in Article 45 paragraph (2) confirms that the agreement does not conflict with religious wedding. In article 47 paragraph (1) Compilation of Islamic Law reads:

"At the time of or before the marriage took place both the bride can make a written agreement approved Servant Marriage registrar on the positions of wealth in marriage "10 Furthermore, the Constitutional Court (MK) with the Number 69 / PUU-XIII / 2015 has made a new breakthrough for the agreement to marry, namely at point one reads: Article 29 paragraph (1) of Act No. 1 of 1974 on Marriage (Statute Republic Indonesia Number 3019) contrary to the Constitution of the Republic of Indonesia Of 1945 to the extent not understood "At the time, before it took place or during the marriage bond mutual consent the parties may file a written agreement approved by the marriage registrar or a notary public servants, after which it shall also apply to third parties throughout the third party stuck ";

Such provisions override pre-existing conditions that mating agreement can only be made before the marriage took place. It is also stressed in the Constitutional Court's decision that the agreement be in writing mating authorized by the employee or Notary marriage registrar. These provisions reinforce who was in charge of the mating ratified the agreement. Previously only mentioned that the mating agreement ratified by the marriage registrar employees but since the enactment of the Constitutional Court Decision mating ratification of the treaty may also be made before a Notary.

In the process, the marriage contract is interpreted not only limited to regulating the mere possessions, but more broadly penetrated about other things, for example, about the duties and responsibilities in the household. Mating agreement can also be done after the wedding because of several factors.

As an illustration of a bride into marriage does not do the marriage contract turned out during the mating behavior of the husband often make mistakes that could harm his wife and possessions belong together, for example, the husband likes to gamble, get drunk so often spend money out of joint property, it certainly would harm his wife and joint property during the marriage or otherwise wives too wasteful in the use of common property that will certainly harm the husband who had to work hard to collect these treasures.

One then draws in this study was the mating agreement made after the marriage took place, so that they will be important and interesting to be studied further. This development can be seen from the possibility that the implementation of the agreement is carried out after marriage mate.

With the above reasons I picked the title "mating validity of the agreement made after marriage under the laws of marriage in Indonesia" by formulating several problems, namely: 1 . What factors made the mating agreement after marriage. 2 . How is the validity of an agreement made after marriage mate. 3. What legal consequences mating agreement made after the course of the marriage.

\section{Research methods}

The research method is a scientific activity that is based on a method, systematics, and certain thoughts which aims to study a particular symptom by way of analyzing it, because research in the social sciences is a process that is done in a planned and systematic way to get troubleshooting and provide conclusions - a conclusion which is not in doubt. ${ }^{11}$ Research is a fundamental tool in developing science and technology that aims to uncover

\footnotetext{
${ }^{10}$ Islamic Law Compilation 1991

${ }^{11}$ Ronny Hanitijo Soemitro 1988 Metodologi Penelitian Hukum Ghalia Indonesia Jakarta p.13.
} 
the truth systematic, methodological and consistent, because it is through the research process conducted analysis and construction of the data has been collected. ${ }^{12}$ The research method used by writer is a normative legal research and empirical jurisdiction. Legal research normative include a study of the principles of law, research on the systematics of law, a study of the level of synchronization of law, legal history and comparative law, while the legal research empirical juridical which includes a study of the identification law (not written) as well as the process of interaction sociological in the establishment and application of the law (the effectiveness of the law). ${ }^{13}$

\section{Results And Discussion}

\subsection{Factors occurrence mating agreement after the holding of marriage.}

The continued development of the situation and the conditions in society, especially with the increasing number of foreign cultural influences into Indonesia, gradually changing lifestyles and perceptions. Treasure each party as well as engaging in marital property becomes an issue highlighted by the couples who want to mate. This is because at this time both the men and women capable of generating assets of each until deemed necessary to regulate the separation of joint property in a marriage. Other factors, for example, mating agreements made by a couple who came from the world of business, where one party has a high-risk business areas which sometimes may decline because it depends on the economic situation. If one of the parties want to apply for credit in the bank with collateral property held, then the debt will be incurred thereafter will only be binding on the relevant parties, while the other will be free of debt payment obligations and risks. Then, if the debtor was declared bankrupt then the wealth which will be seized by a creditor, while property partner was not. Not only a limited set of the treasure alone, but more broadly penetrated about other things, for example, about the duties and responsibilities in the household, for example, include the agreement that it refers to the Law on Domestic Violence, as it can only after a few months of marriage lasts husband turns like getting drunk and spending the money for the common interest (family).

\subsection{Validity of the agreement after the course of a marriage mate.}

According to the provisions of Article 29 Marriage Law, marriage agreement endorsed by the Marriage Registrar Officer. On Article 29 of the Marriage Act does not mean that if the marriage agreement is not sisahkan by the Marriage Registrar Employee Agreement is invalid marriages. Ratification is done by doing the bookkeeping or recording of the marriage agreement in the book list that is provided for registration. Registration of marriage agreement after the enactment of the Marriage Law is no longer practiced in the District Court Clerk's Office but conducted by the Marriage Registration Officer at the Civil Registry Office (Office of Population and Civil) or the Office of Religious Affairs.

Validity of mating agreement executed after the course of a marriage that is with the release of a Constitutional Court decision No. 69 / PUU XIII / 2015, the changes relating to the manufacture of the Marriage Covenant. If previous marriage agreement can only be made before or at the time of marriage only, the present Agreement may also be made by the marriage of husband and wife throughout their marriage. With the decision of the Constitutional Court that the couple, before or at the time the marriage took place not

\footnotetext{
${ }^{12}$ Suparmoko 1991 Metode Penelitian Praktis Yogyakarta p. 1.

${ }^{13}$ Fajar Mukti and Achmad Yulianto 2010 Dualism Normative and Empirical Legal Research Pustaka Pelajar Yogyakarta p. 153-155
} 
make agreements marriages, if they want to make the Treaty marriages throughout their marriage does not ask the Court Decision for the purposes of making a Covenant Marriage is, as has happened several times.

2.3 Legal consequences mating agreement after the course of the marriage

- The legal consequences for those who make it: Married Development Agreements with the approval of both parties that the couple after the marriage took place.

- The legal consequences of property: Viewed from the case that gave birth to the Constitutional Court decision resulted in the Marriage Covenant out of fellowship property or separate property Mating Agreement be anything.

- The legal consequences of the Third Parties: Agreements are made binding on third parties.

\section{Closing}

\subsection{Conclution}

- Factors mating agreement after the course of the marriage, matters regarding property arrangements, duties and responsibilities, etc.

- Validity of mating agreement made after marriage in Act No. 1 of 1974 concerning marriage and Compilation of Islamic Law that is created and registered by the Registrar of Marriage Officer. In the Decision of the Constitutional Court Number 69 / PUU XIII / 2015 mating agreement can be made after berangsungnya marriage and Notary.

- As a result of the Marriage Covenant law created after the marriage, among others: the legal consequences for those who make it, due to the law of property, and legal effect against third parties.

\subsection{Suggestion}

- 4.2.1 For the Government, soon to renew the Marriage Act in order between the rules and the other one to avoid misunderstandings or overlapping.

- 4.2.2 For People today, who have made a pact to marry and need to immediately make the Decision of the Constitutional Court that the legal basis in the making.

\section{Bibliography}

[1] Fajar Mukti and Achmad Yulianto 2010 Dualism Normative and Empirical Legal Research Pustaka Pelajar Yogyakarta.

[2] R. Soetojo Prawirohamidjojo 2000 Hukum Orang Dan Keluarga (Personen En FamilieRect) Airlangga University Press Surabaya.

[3] Ronny Hanitijo Soemitro 1988 Metodologi Penelitian Hukum Ghalia Indonesia Jakarta.

[4] Suparmoko 1991 Metode Penelitian Praktis Yogyakarta.

[5] Act No. 1 of 1974 on Marriage

[6] Islamic Law Compilation Book I on Marriage

[7] Constitutional Court Decision Number 69 / PUU-XIII / 2015

[8] https://indonesia.embassy.gov.au/jakt/marriageind.html accessed on 02 December 2018

[9] https://www.voanews.com/a/in-indonesia-interfaith-marriage-is-legal---but-withmany-obstacles-/4373874.html accessed on 02 December 2018 